\title{
Object and Principles of Digital Policy Implementation
}

\author{
Shcherbakova L.N.* \\ Department of Economic Theory and Public Administration \\ Kemerovo State University \\ Kemerovo, Russia
}

Zobova L.L.

Department of Economic Theory and Public Administration Kemerovo State University

Kemerovo, Russia

\author{
Evdokimova E.K. \\ Department of Economic Theory and Public Administration \\ Kemerovo State University \\ Kemerovo, Russia \\ E-mail: elena_evdokimova@inbox.ru
}

\author{
Kusurgasheva L.V. \\ Department of Economics \\ Gorbachev Kuzbass State Technical University \\ Kemerovo, Russia \\ E-mail kusurgashevalv@mail.ru
}

\begin{abstract}
The paper discusses digital policy as a qualitatively new stage of information policy. Digital policy is presented as a set of organizational measures based on the scientifically justified introduction of digital technologies into the economy. The paper presents the object of digital policy as a derivative of the essence of digital economy. The authors argue that the object of digital policy includes such phenomena of the digital economy as the assessment of quantitative results of digitalization; the specifics of digital divide and its forms; synergistic and diversified nature of today's digital life; the inconsistency of the impact of information resource on economic growth, economic structure and social processes; and the systematic quality development of the information society. Besides, four principles of building a digital policy are revealed. 1) Segmentarity implies that the essence of digital policy should depend on: a) its object and the sector that is the object of digitalization (for example, agriculture or the banking sector); b) the nature of the information technologies used (cellular communication or convergent technologies). 2) Multivariance implies the dependence on the chosen model of the digital society. Three possible models of information economy formation are identified: small-scale digitalization, large-scale digitalization, and a full-fledged information society. 3) Interlinking with the structural and innovative nature of the changes that are taking place is relevant since information technologies are innovative products and they have a contradictory impact on the economy. 4) Digital policies must combine a discretionary and nondiscretionary nature to ensure that the positive and negative effects of digital technologies are adequately reflected. Conclusion: The proposed principles should be taken into account in the implementation of digital policy.
\end{abstract}

Keywords - digital economy, object of digital policy, digital policy principles, discretionary and non-discretionary digital policy.

\section{INTRODUCTION}

A global modern trend in the development of global and national economies is the qualitative transformation of the technological basis due to universal digitalization, and the penetration of information and communication technologies
(ICT) in all spheres and levels of the society. The term "digital economy" (or "API economy" in the United States) is becoming more widely used. Its essence is far from being universally recognized, which indirectly indicates that economic theory is lagging behind practices. In this regard the major task is to determine the essence of the economy that is replacing the industrial economy. However, from a practical point of view, another issue is more important: namely, understanding the relations between the market and the state.

It is obvious that if digital products are defined as a public good, then in the case of the digital economy we are dealing with a classic "market failure". However, the analysis shows that the economic policy based on neoclassical postulates is outdated and does not correspond to the new digital economy [1]. Moreover, within the framework of this theory, there is no place for digital policy as a special direction of the activity of the state in the economic sphere. Hence, it is essential to develop the conceptual basis for such a policy, to show its necessity and to fill it with meaningful content. Modern research emphasizes that Russia's entry into long-term economic growth is possible only through qualitative changes in the investment structure, improving the efficiency of state management and the country's competitiveness [2]. The set tasks are closely related to Russia's policy of digitalization of the economy. This work aims to define the object and principles of digital policy. The objectives of the study are: determining the ratio of the essence of the digital economy and policy; identifying the components of the object of digital policy; and formulating the principles of digital policy.

\section{METHODS AND MATERIALS}

Statistical data from international and Russian organizations, documents of the Government of the Russian Federation, and analytical publications by Russian and foreign scientists were used as the material for the study. The research tasks were addressed basing on the principles of the dialectical-materialistic method of cognition and the use of system, world-system, and synergistic approaches; the method 
of formalized analysis was used as well. A synergistic approach is necessary to represent the diversified penetrating nature of a modern information resource.

\section{RESULTS}

\section{A. The essence of the digital economy}

Like any innovation, digital technologies, have gone through two stages of development. The first stage is characterized by latent, internal development; the second stage implies the active use of new technologies in the economy. Accordingly, the first stage was characterized by the term "information policy", which was perceived as a set of ways to reproduce and distribute information, including information protection as its most important part. Within the second stage, digital policy becomes dominant. It should aim at organizing the process of effective implementation of information technologies in economic and social processes, developing and implementing the measures to digitalize the economy.

Globally, the use of information technologies in the economy is not a new trend. Theoretically, this issue has been studied by foreign authors for more than a decade [3, 4]. However, for Russia, which lost a solid potential for information development due to market reforms in the 1990s, setting the goal of establishing an information economy is partly new. For businesses and management structures, it is difficult not only to organize the digitalization process, but also to understand its essence, prospects, mechanisms, and effectiveness. Therefore, the principles of organizing digital policy should be formulated based on an understanding of the essence of the digital economy, primarily its reality.

The starting point for identifying any type of economic policy is the identification and recognition of the reality of the phenomenon (process) that will become the object of its regulatory impact. Despite the fact that the concept of the digital economy is firmly established in our lives [5], not all researchers consider the information economy or digital economy to be a relevant topic. Some scientists believe that it exhausted its potential at the end of the $20^{\text {th }}$ century with the use of computers and cellular communications, especially since at that time some researchers disagreed with the statement about the impact of information technologies on labor productivity growth $[6,7]$. Some Russian experts tend to define the "digital economy" as a "fashionable term", which is widely used due to the issuance of the next order of the government, rather than the appearance of new theoretical results and changes in the structure of the real economic system [8]. Others consider the information economy as a phantom, and researching it as harmful activity as it leads the science away from real economic problems. It is suggested that the digital economy is a simulacrum (a sham), giving no quality development to either a person or the society [9].

The arguments against such opinions are the following. Firstly, the improvement of information technology has almost no borders; there is evidence that the digital revolution will last for 140 years (and possibly more). Secondly, the second wave of the information revolution is currently underway, including the development of a Comprehensive Internet, cloud and converged technologies, the Internet of Things, and Big Data $^{1}$. Thirdly, the reality of the digital economy and the huge degree of its penetration into the functioning sector is significantly mistaken due to the imperfection of statistical accounting of its results: the new economy goes past statistics $^{2}$.

From a theoretical and methodological point of view, the specificity of the object of digital policy is that it depends on the conceptual aspects of the digital economy. The concept of the digital economy is interpreted in different ways, and it can be argued that it has not yet found a final definition. Even the comparing the terms "information economy" and "digital economy" is difficult. The literature presents a range of points of view ranging from heir synonymy to categorical opposition. Their categorical opposition is explained by the fact that the information economy emerged as a result of the third industrial revolution, and its main resource was information, while the digital economy originates from the fourth industrial revolution, and its resource is "digital data" [10].

\section{B. Components of the object of digital policy}

The authors argue that the information and digital economies differ in the level of development of information technologies, while their economic essence is the same. Thus, when comparing the most significant definitions of the information economy and the digital economy, three important and recurring aspects are found in them: relations (activities, sector, markets, stage of development), reliance on information and communication technologies (social networks, the Internet, programming, e-Commerce, convergent technologies, etc.) and the result - changes in all spheres of the economy and the society (economic structure, economic growth, labor markets, management, human behavior, etc.) $[11,12]$. The conceptual aspects of the digital economy, that is, it is most important components are: quantitative assessment, the new quality of the information resource, the digital divide and the importance of overcoming it, structural changes in the economy and the labor market, and new forms of economic and social deformations that accompany the introduction of digital technologies. Accordingly, each of the presented aspects of the digital economy should be included in the object of digital policy. The specificity of the components of the object of digital policy is revealed in its separate directions.

\section{Quantitative assessment of the digital economy}

The aggregate of data on the digital economy is underestimated for many reasons, namely: 1) the products of the digital economy are largely intermediate; 2) the results of information activities are often included in other parameters, such as innovations or related services; 3) information products are usually virtual, so only the cost of materials and material carriers, but not the information itself is taken into account; 4) the number of people working in the digital

\footnotetext{
${ }^{1}$ Cloud Technology essay. Available at: https://graduateway.com/cloudtechnology/ (accessed 06.05.2019).

2 Digital Economy \& Society in the EU. Available at: http://ec.europa.eu/eurostat/cache/infographs/ict/2018/index.html (accessed 22.04.2019)
} 
economy is clearly underestimated, there is no full accounting not only for "electronic freelancers" (people with double employment who earn money on the Internet after work), but also for those professionals who spend a significant part of their working time on working with information (teachers, doctors, researchers, scientists, and managers of different levels). It should be noted that in the basic works on the information society, the following categories of workers employed in three areas were considered information workers: "knowledge workers", "data workers", and "information workers" ("information-producing workers" and "informationusing workers"), i.e. the people who do not only produce new knowledge, but also work with information, as well as those engaged in repairing digital equipment [13].

There is a clear need to update the national accounts system in order to objectively assess the results of the digital economy. The latter can be successfully developed only on the basis of an adequate quantitative assessment of the functioning of the digital sector and a reliable measurement of its final results. At the moment, both the production method of calculating added value and the distribution method of calculating income are practically inapplicable to the economic links of the Internet sector. The national accounts system itself is not able to reach the level of detailed statistical information which is necessary to reflect the results of the digital economy. As a result, either data on Internet activity is not reflected, or there is confusion between the assessment of online and offline activities in the digital economy. Only the method of end-use of income, according to which the Internet economy is measured by including final consumption, gross capital accumulation, government spending, and net exports, has found a certain application in the calculations [14]. Some firms are developing their own proxy-indicators of the performance. Thus, improving the ways of evaluating the digital economy indicators should become one of the objects of concern for digital policy.

\section{Diversified and synergistic nature of the digital resource}

The most convincing argument that confirms the existence of the digital economy is the emergence of a new modern information resource. The special nature of the digital resource is explained by two facts: firstly, it has a global origin and acts as an external factor in relation to the macro and micro levels of the economy, and secondly, it is diversified, which means that it can serve all segments of the economy, both because of its intangible nature and because of its demand. The first property of the resource provides a synergistic effect on the economy. The digital resource, being an external stimulus for the system, provides its resonant activation. Responding to this push, the system itself implements a feedback effect: the level of intellectualization of production increases, spreading to all sectors of economic activity.

The diversified nature determines the equal possibility of using material carriers of information technologies in different industries; the only difference is in the use of associated software services. It is its property of functioning exclusively on the basis of knowledge, education, intellectual capital, science, i.e. on the intellectual infrastructure that gives the digital resource its unified character [15]. The digital resource can improve the quality of management, regardless of the field of activity. Collecting information, analyzing it, developing a solution for the production area under study, and passing the solution to the lower stages can be qualitatively improved by using the digital factor of production. It is the diversified nature of modern information that justifies the transformation of the information sector into a driver of economic development.

Resources can be substitutional and complementary, and information as a factor of production can be both. The substitutional effect is reflected in the fact that e-Commerce is already replacing traditional advertising, Internet advertising is replacing advertising on television and on paper, and egovernment is replacing the office bureaucracy, which leads to the decrease in costs. The complementary nature of the digital resource gives dynamism to the functioning of traditional factors of production, since they are joined by information flows of a qualitatively new level; convergent technologies, the Comprehensive Internet and software increase the overall efficiency of production. Mathematical justification of the impact of digital technologies on the economy is usually carried out using the Cobb-Douglas function (which is typical for calculating the impact of any innovation) [16]. Russian economists evaluated the impact of digital technologies by comparing the results obtained when digital technologies were initially excluded from investment, and then when they were introduced, and quantitatively proved the contribution of digital technologies to the development of regions. Still, its reliable quantitative assessment is difficult for a number of reasons. So, digital policy should be based on knowledge and use of the properties of a digital resource.

\section{E. Digital divide}

The IT revolution has brought to life a new social phenomenon - the digital divide. At the global level, it is defined as the gap between countries within the core of the Internet and countries on its periphery, lacking skills, resources, and infrastructure [17]. Research on this problem was parallel to the study of the information economy itself. The ICT Development Index (IDI) developed by the United Nations International Telecommunication Union and based on annually collected data on the promotion of digital technologies can serve as an indicator of ICT differentiation of countries.

In the 2000s, the growth rate of Internet usage and penetration (as indicators of the information society) is higher in middle - and underdeveloped countries than in developed countries (Table I).

On this basis, there was an opinion about the elimination of the digital divide, and the absence of need to assist the developing countries in information development. However, in modern conditions, there are many reasons for the deepening and dominance of digital differentiation [18]. It is necessary to distinguish between technical and economic aspects in the quantitative representation of the digital divide, that is, in addition to purely technical estimates (for example, the number of Internet users), it is necessary to take into 
account income inequality resulting from the use of information technologies.

TABLE I. INTERNET USAGE GROWTH RATE 2000-2019 BY WORLD REGIONS $^{3}$

\begin{tabular}{|c|c|c|c|c|}
\hline $\begin{array}{c}\text { World } \\
\text { regions }\end{array}$ & $\begin{array}{c}\text { population, } \\
\mathbf{2 0 1 9}\end{array}$ & $\begin{array}{c}\text { Internet } \\
\text { Users, as of 31 } \\
\text { March 2019 }\end{array}$ & $\begin{array}{c}\text { Internet } \\
\text { penetration } \\
\text { rate (\% of the } \\
\text { population) }\end{array}$ & $\begin{array}{c}\text { Growth } \\
\text { rate } \\
\mathbf{2 0 0 0 -} \\
\mathbf{2 0 1 9}\end{array}$ \\
\hline Africa & 1320038716 & 492762185 & 37.3 & $11.2 \%$ \\
\hline Asia & 4241972790 & 2197444783 & 51.8 & $50.1 \%$ \\
\hline Europe & 829173007 & 719365521 & 86.8 & $16.4 \%$ \\
\hline Middle East & 258356867 & 173542069 & 67.2 & $4.0 \%$ \\
\hline $\begin{array}{c}\text { North } \\
\text { America }\end{array}$ & 366496802 & 327568127 & 89.4 & $7.5 \%$ \\
\hline $\begin{array}{c}\text { Latin } \\
\text { America / } \\
\text { Caribbean }\end{array}$ & 658345826 & 444493379 & 67.5 & $10.1 \%$ \\
\hline $\begin{array}{c}\text { Oceania / } \\
\text { Australia }\end{array}$ & 41839201 & 28634278 & 68.4 & $0.7 \%$ \\
\hline World total & 7716223209 & 4383810342 & 56.8 & $100 \%$ \\
\hline
\end{tabular}

The allocation of two forms - replenishing and dynamic can give bring a certain explicitation of the category of digital inequality [19]. The replenishing digital inequality reflects the initial stage of the information economy and is almost similar to the already existing relations of inequality. Dynamic digital inequality is formed at a more mature stage of the information society, when the leaders of digital markets use competitive advantages and the specifics of information technologies as a tool in information wars, a means of increasing advantages and obtaining economic benefits [20]. The unequal degree of development of e-Commerce, e-government, proprietary software, the level of import dependence of industries that produce information technology, the possibility of using convergent cloud technologies, and Big Data become the basis for further deepening of economic inequality. So, another goal of the digital policy should be to focus on overcoming digital inequality.

\section{F. Structural changes in the economy and labor market}

A new quality information resource, like other innovative phenomena, can have an ambiguous effect on economic growth, the structure of the economy, and social processes. On the one hand, a new information sector is being formed, whose structure is not defined, although it is obvious that it is constantly and dynamically changing and becoming more complex. The labor market is also changing structurally, new professions are emerging, and the process of active shifting of employees to the virtual sphere is taking place [21]. Activities related to the creation and maintenance of websites, blogs, services, advertising in electronic space, and working with social networks are becoming popular $[5,22]$. There is a growing demand for new specialists: copywriters, remote

\footnotetext{
a. Compiled by the authors based on: The Internet Big Picture. World and 2019 Population Stats Internet Users. Miniwatts Marketing Group, 2019. Available at: https://www.internetworldstats.com/stats.htm (accessed 02.05.2019)
}

accountants, web designers, online consultants, video editing and contextual advertising specialists.

\section{G. New forms of economic and social deformations that accompany the introduction of digital technologies}

The virtual nature and speed of the modern digital resource are used by opportunistic layers of society for their own selfish purposes, distorting both the producing sector of the national economy and the social processes in the society. Firstly, there are areas of activity where the use of digital technologies can provide a rapid innovation effect, but their subsequent accelerating dynamics violates the optimal proportions of economic development (e.g. the disproportion between the real sector and the financial sector [23], the excessive expansion of the advertising industry, the emergence of illegal e-Commerce and direct fraud in Internet Commerce). Secondly, the benefits of using information technologies are often obtained by entities or structures either operating on an illegal basis, or focused on cybercrime, or having the possibility of an exclusive right to information (bureaucracy). Thirdly, information technologies are used for conducting information wars and, as a result, weakening the enemy with a corresponding decrease in its economic potential. Fourthly, the rapid growth of digital technologies can negatively affect the health capital of the nation, as the electronic revolution with the help of advertising causes an acceleration of economic growth, the increase in consumption of natural resources, and a new stage of exacerbation of environmental problems; the technology, particularly mobile communications, have a negative impact on the environment [24]. Digital technology is subject to rapid aging, which requires frequent replacement, leading to an overall increase in the amount of waste; finally, computer-related activities harm the health of employees, causing occupational diseases. Thus, digital policy must work closely with structural policy.

\section{DISCUSSION}

\section{A. Features of digital development in Russia}

In Russia, the process of informatisation of the society began later than in developed countries. But since the mid-2000s, the average growth rate of the digital economy in the country has been 30-40 \% . Over the past five years, the indicators of the information society in Russia have generally tended to grow, despite the economic shocks and fluctuations in the Information Development Index (moving from the 41th to the $45^{\text {th }}$ place) ${ }^{5}$. The weakness of Russia's information development lies in the continuing dependence of IT production on the import of components, the absence of a well-established mechanism for using e-Commerce, a low level of e-government development, and an outflow of software specialists or their products abroad [25].

\footnotetext{
${ }^{4}$ Calculated by the authors based on: State Statistic Service of the Russian Federation (Rosstat). Indicators of information society development. URL: http://old.gks.ru/wps/wcm/connect/rosstat_main/rosstat/ru/statistics/science_a nd_innovations/it_technology/\# (accessed 06.01.2020).

5 Measuring the Information Society Report 2018.Volume 1. Geneva: International Telecommunication Union, 2018, 190 p. Available at: https://www.itu.int/en/ITU-D/Statistics/Pages/publications/misr2018.aspx (accessed 15.06.2019).
} 
As the economy is currently in need of new sources of growth, digital technologies can serve as alternative development factors, thanks to the substitutional and complementary character of the digital resource. A wellconducted digital policy can ensure an increase in added value, a drop in production and business costs, and a rise in the quality of management to a new level. Optimization of the structure of the Russian economy is possible through the correct application of information technologies in certain sectors, including science, industry, raw material sector, trade, education, and health care.

\section{B. Principles of digital policy implementation in Russia}

The principles of digital policy are formed as directly dependent on the phenomena and problems of the digital economy that were presented as components of the object of digital policy. The study revealed the following principles.

1) Segmentarity. Segmentarity of digital policy indicates that its essence depends on the segment or sector that is being digitalized (for example, agriculture or banking) as well as on the nature of the information technologies used (cellular communications or converged technologies). The agricultural sector is characterized by the spread of a system of open information data on innovations in the technological field, on the volume of trade in agricultural products, and on the variety of farming methods. It is also characterized by improving the information literacy of rural workers and the availability of digital technologies in rural areas, developing skills for working with sites and relevant information resources. In the industry, it is the possibilities of using electronic Commerce with the subsequent expansion of its share in relation to the leading industrial sectors that are considered in the first place. Each industry has certain conditions for the development of eCommerce: a standardized product, well-established distribution networks, and a high level of competitiveness.

2) Choice of the model of the digital society. It is most realistic to talk about three possible models of the digital economy: small-scale digitalization, large-scale digitalization, and a full-fledged information society. The small-scale digitalization model is based on effective, well-elaborated application of relatively inexpensive digital technologies (most often imported) in all industries and areas of activity, with subsequent savings in resources and increase in the efficiency of the economy. The economic effect is based on the displacing effect of the digital resource. This path is mainly taken by developing countries. Large-scale digitalization involves all the elements of the first model plus a comprehensive application of the latest progressive digital technologies (convergent technologies, Comprehensive Internet, Big Data, the Internet of Things), and the country is focused mainly on its own technical base. Comparing the data on the share of exports of information and communication products in individual countries shows that for 30 countries this share is less than $0.2 \%$ of the total export structure (for example, Ethiopia, Honduras, Kuwait, Moldova, etc.). There are 19 countries with a share of digital goods exports ranging from 4 to $45 \%$, including Germany, the United
States, Thailand, Hong Kong, etc ${ }^{6}$. A distinctive feature is that the share of imports of these goods is higher in developed countries. The opportunities for digital development are definitely higher in countries with an active market for digital goods.

The new quality of the digital society and the full realization of the potential of the information economy correspond to the model of a full-fledged information society. The features of the new society include the elimination of private property, the elimination of the vertical hierarchy in the management of its horizontal structure, and the dominance of a new subject - the socio-economic community [26]. The Comprehensive Internet, Big Data, cloud technologies, and social networks operate on the basis of integrative mechanisms.

3) Acknowledgement of the innovative nature of digital technologies. The specific feature of digital policy is its interlinking with innovation policy. Digital technologies are in the nature of innovative products. The peculiarities and inconsistencies of the latter must be taken into account when conducting digital policy. A country that has a certain digital lag has a choice of two options: it may make an innovative breakthrough, being a leader in one or many areas of digital development, or it may follow the path of small-scale digitalization based on the diffusion of knowledge and technologies from more advanced countries in this market. As part of Russia's innovative development, attention should be paid to the implementation of the following steps in the field of digitalization of the economy:

- developing national production of components (chips) for the formation of a full-fledged domestic sector of personal computer production;

- providing for leading positions in breakthrough areas of the digital economy, in particular, in the production of convergent technologies, Internet things or products made with $3 \mathrm{D}$ printers;

- struggling to keep employees who produce their own software within the Russia.

4) Combination of discretionary and non-discretionary digital policies. Combining discretionary and nondiscretionary digital policies requires careful calculations that take into account all possible consequences, including socioeconomic deformations. For this reason, digital policy should be both discretionary and non-discretionary in nature, which would provide adequate reflection on the various kinds of consequences of using digital technologies, both positive and negative.

The digital economy of the Russian Federation is developing on a legal basis. Russia has gone a long way from implementing the Concept of state information policy and the Concept of forming an information society in Russia to the National program "Digital economy of the Russian

6 Calculated by the authors based on: Measuring the Information Society Report 2018.Volume 1. Geneva: International Telecommunication Union, 2018, 190 p. Available at: https://www.itu.int/en/ITU-D/Statistics/Pages/ publications/misr2018.aspx (accessed 15.06.2019). 
Federation". It is a set of measures for digitalization of the economy and ensuring information security and equal access of people to new technologies that forms the core of a nondiscretionary digital policy. At the same time, it is necessary to respond to the structural deformations that accompany the dynamics of the digital sector by applying current additional discretionary measures. In particular, it is necessary to take into account the trend of increasing electronic fraud, bureaucracy, increasing difficulties in taxation of electronic freelancers, the outflow of Russian programmers abroad, the lack of material resources for remote employment, and the overbalance of the drawing advantages of the digital revolution in the financial and advertising sphere.

The study allowed developing the following principles for implementing Russia's digital policy (Table II).

TABLE II. CORRELATION OF PRINCIPLES AND INSTRUMENTS OF DIGITAL POLICY IMPLEMENTATION

\begin{tabular}{|c|c|c|}
\hline Principle & $\begin{array}{l}\text { Object and the } \\
\text { existing problem of } \\
\text { digital development }\end{array}$ & Instruments \\
\hline Segmentarity & $\begin{array}{l}\text { Segment of the } \\
\text { economy, nature of the } \\
\text { information } \\
\text { technologies used }\end{array}$ & $\begin{array}{l}\text { Choice of digital } \\
\text { technologies depending on } \\
\text { the sphere of activity }\end{array}$ \\
\hline $\begin{array}{l}\text { Multivariance } \\
\text { of the digital } \\
\text { economy } \\
\text { model }\end{array}$ & $\begin{array}{l}\text { Choice of the model: } \\
\text { small-scale } \\
\text { digitalization, large- } \\
\text { scale digitalization, or } \\
\text { a full-fledged } \\
\text { information society }\end{array}$ & $\begin{array}{l}\text { A) coverage of the number } \\
\text { of digital economy sectors; } \\
\text { B) the degree of provision } \\
\text { of the country's national } \\
\text { digital equipment; } \\
\text { C) readiness for production } \\
\text { and application of new } \\
\text { generations of digital } \\
\text { equipment and } \\
\text { technologies }\end{array}$ \\
\hline $\begin{array}{l}\text { Interlinking } \\
\text { with } \\
\text { innovation } \\
\text { policy }\end{array}$ & $\begin{array}{l}\text { Dependence on } \\
\text { imports, absence of } \\
\text { domestic production of } \\
\text { digital goods within } \\
\text { the 4th industrial } \\
\text { revolution; the brain } \\
\text { drain and the digital } \\
\text { economy }\end{array}$ & $\begin{array}{l}\text { Diffusion of knowledge } \\
\text { and technologies; rejection } \\
\text { of low-quality imports of } \\
\text { digital technology; } \\
\text { development of national } \\
\text { digital production; ensuring } \\
\text { leadership positions in } \\
\text { breakthrough areas of the } \\
\text { digital economy }\end{array}$ \\
\hline $\begin{array}{l}\text { Combination } \\
\text { of } \\
\text { discretionary } \\
\text { and non- } \\
\text { discretionary } \\
\text { nature of the } \\
\text { digital policy }\end{array}$ & $\begin{array}{l}\text { Deformations of the } \\
\text { digital society and } \\
\text { economy: electronic } \\
\text { fraud, bureaucracy, } \\
\text { taxation of electronic } \\
\text { freelancers, outflow of } \\
\text { Russian programmers } \\
\text { abroad, new } \\
\text { deformations of the } \\
\text { economic structure } \\
\text { (financial and } \\
\text { advertising spheres). }\end{array}$ & $\begin{array}{l}\text { Monitoring of socio- } \\
\text { economic changes in the } \\
\text { digital society and } \\
\text { responding to new } \\
\text { deformations: } \\
\text { differentiation of taxation } \\
\text { of various forms of e- } \\
\text { business, countering } \\
\text { bureaucracy, increasing the } \\
\text { openness of the } \\
\text { management system, } \\
\text { developing a mechanism } \\
\text { for preventing electronic } \\
\text { fraud. }\end{array}$ \\
\hline
\end{tabular}

\section{CONCLUSION}

During the implementation of state's digital policy, it is necessary to take into account its relationship with structural and innovation policies. Digital policy should develop and expand as it covers certain segments of the economy and the society. Since the structural adjustment of national economies under the influence of information technologies is nondiscretionary, it is necessary to predict and take into account new undesirable changes using the levers of discrete digital policy. Finally, digital policy makes sense only within the chosen model of digital development, that is, when its goals, instruments, and possible outcomes are clearly defined.

\section{References}

[1] R. Bukht, R. Heeks, Digital Economy Policy in Developing Countries. Manchester: Arthur Lewis Building, 2018, 28 p.

[2] M. Oreshkin, "Prospects of Economic Policy", Econ. Policy, no. 3, pp. 8-27, 2018.

[3] P.A. David, "The Dynamo and the Computer: An Historical Perspective on the Modern Productivity Paradox", The Amer. Econ. Rev., vol. 80, no. 2, pp. 355-361, 1990.

[4] M. Carnoy, M. Castells, S. Cohen, F. Cardoso, The New Global Economy in the Information Age: Reflection on Our Changing World. Pensilvania: Penn State Univer. Press, 1993, 176 p

[5] E. Sadovaya, "The Digital economy and a New paradigm of the labor market", World Econ. and Int. relat., vol. 62, no. 12, pp. 35-45, 2018. DOI: 10.20542/0131-2227-2018-62-12-35-45.

[6] R.M. Solow, We'd Better Watch Out, New York Times Book Review, July 12,1987

[7] R.J. Gordon, "The Jobless Recoverty: Does It Signal a New Era of Productivity-Led Growth?", Brucing Papers on Econ. Activity, no. 24, pp. 271-316, 1993.

[8] V.A. Plotnikov, "Digitalization of production: the theoretical essence and development prospects in the Russian economy", Proceedings of Saint Petersburg State University of Economics, 2018, no 4 (112), pp.16-24.

[9] T. N. Yudina, Digital Economy: some aspects of pro et contra (artificial intelligence, blockchain and cryptocurrencies, labor productivity)", Philosophy of economics, In: Almanac of the Center for Social Sciences and Economics of Lomonosov Moscow State University. Special edition, December 2017, pp. 112-121.

[10] T.N. Yudina, Yu.M Osipov, and I.Z Geliskhanov, "Information-Digital Economy: Concept, Basic Parameters and Implementation Mechanisms", Moscow Univer. Econ. Bull., Ser. 6, Econ., no 3, pp. 41-60, 2019.

[11] K. Shvab, The Fourth Industrial Revolution. Moscow: Eksmo, 2016, $565 \mathrm{p}$.

[12] A.V. Keshelava (Gen. ed.), On the cusp of a digital future, Book One. Moscow: VNII Geosystem, 2017, 29 p.

[13] V.L. Inozemtsev, The Split civilization. Moscow: Nauka Publ., 1999, $724 \mathrm{p}$.

[14] S. Plaksin, G. Abdrakhamova, G. Kovaleva, "Internet economy in Russia: approaches to definition and evaluation", Foresight, vol. 11, no. 1, pp. 55-65, 2017. DOI: 10.17323/2500-2597.2017.1.55.65.

[15] A.A. Bakarov, D.A. Devyatkin, T.V. Ershova, et al., "Russia's Scientific Background in the Area of Cross-cutting Technologies of Digital Economy", Inform. society, no. 4-5, pp. 54-64, 2018.

[16] V. Malein, Yu Ponomarev, "Analysis of the Impact of New Technologies in Metallurgy on the Industry Production Function and Total Factor Productivity”, Econ. Policy, no. 3, pp. 132-151, 2019.

[17] W. Chen, B. Wellman, "The Global Digital Divide Within and Between Countries", IT and Society, vol. 1, no. 7, pp. 39-45, 2004.

[18] A. Berg, E.F. Buffie, L.F. Zanna, "Robots, Growth, and Inequality", Finance \& Development, vol. 53, no. 3, pp. 10-13, 2016.

[19] V.A. Shabashev, L.N. Shcherbakova, "Trends of digital equality / divide in the modern world", Sociological res., no. 9, pp 3-12.

[20] A. Bereznoi, "Transnational business in the era of the global digital revolution", World Econ. and Int. relat., vol. 62, no. 9, pp. 5-17, 2018. DOI: 10.20542/0131-2227-2018-62-9-5-17.

[21] Y.A. Salikov, I.V. Logunova, I.V. Kablashova, "Trends in human resource management in the digital economy", Proc. of Voronezh State 
Univer. of Engineer. Technol., vol. 81, no. 2, pp. 393-399, 2019. Retrieved from: https://doi.org/10.20914/2310-1202-2019-2-393-399

[22] C.B. Frey, M.A. Osborne, "The future of employment: How susceptible are jobs to computerization?", Technol. Forecast. and Soc. Change, vol. 114, pp. 254-280, 2017.

[23] Ya. Kregel', "Minsk and International Development Finance", Econ. Policy, no. 4, pp. 8-19, 2018.

[24] L. Zobova, L. Shcherbakova, E. Evdokimova, S. Savintseva, "Features of information technologies influence on social development", vol. 198, pp.70-75 [Int. Conf. on the Theory and Practice of Personality
Formation in Modern Society (ICTPPFMS-18) "Advances in Social Science, Education and Humanities Research"]. DOI: 10.2991/ictppfms18.2018 .13

[25] N.A. Serebryakova, I.V. Avdeev, "The essence of structural transformations of the region's economy, adequate to the requirements of digitalization", Proc. of Voronezh State Univer. of Engineer. Technol., vol. 80, no. 4, pp. 408-412, 2018. Retrieved from: https://doi.org/10.20914/2310-1202-2018-4-408-412

[26] E. Masuda, "The Computopia", Philos. and Soc. Life, no. 6, pp. 36-50, 1993. 